\title{
Seismic reflection evidence for a Dangerous Grounds mini-plate in the South China Sea and implications for extrusion tectonics in SE Asia
}

\author{
Peter Clift', ${ }^{2 *}$, Gwang H Lee ${ }^{3}$, Nguyen Anh Duc ${ }^{4}$, Udo Barckhausen ${ }^{5}$, Hoang Van Long ${ }^{1}$ and Sun Zhen ${ }^{2}$ \\ 1 School of Geosciences, University of Aberdeen, Aberdeen, AB24 3UE, UNITED KINGDOM \\ ${ }^{2}$ Key Laboratory of the Marginal Sea Geology. South China Sea Institute of Oceanology, Chinese Academy of Sciences, 164\# Xingangxi Road, \\ Guangzhou, 510301, CHINA \\ 3 Department of Environmental Exploration Engineering, Pukyong National University, Busan 608-737, KOREA \\ 4 Vietnam Petroleum Institute, Yen Hoa, Cau Giay, Hanoi, VIETNAM \\ 5 BGR, Federal Institute for Geosciences and Natural Resources, Stilleweg 2, 30655 Hannover, GERMANY \\ * For correspondance, email: pclift@abdn.ac.uk
}

The collision of India and Asia has caused large strike-slip faults to form in East Asia, resulting in the "extrusion" of crustal blocks towards the southeast since the Eocene as a result of the indentation of rigid India into Asia (Peltzer and Tapponnier 1988, Tapponnier et al. 1982). It has been suggested that the South China Sea opened as a result of relative motion between a rigid Indochina (Sundaland) block and China (Briais et al. 1993). Alternative models propose that rifting and seafloor spreading were driven by trench forces to the south (Morley 2002, Taylor and Hayes 1980). We test these competing models by analysis of seismic reflection profiles across the boundary between Sundaland and the southern rifted margin, known as the Dangerous Grounds. We show that the southern boundary of the Dangerous Grounds is a subduction zone that jammed in the Middle Miocene (Hutchison et al. 2000). To the west the Dangerous Grounds is bounded by a strike-slip zone, also active until $\sim 16 \mathrm{Ma}$, that becomes diffuse south of the now inactive South China Sea seafloor spreading centre. We place the western edge of the Dangerous Grounds just to the east of the Natuna Arch (Lupar Line). The West Baram Line is confirmed as originating as a major strike-slip fault within the Dangerous Grounds and continuous with Red River Fault Zone. Because the Dangerous Grounds were independent of Sundaland until $\sim 16$ Ma its motion cannot have been constrained by motion of this block, making extrusion impossible as a mechanism to rift the South China Sea. SE motion by both the Dangerous Grounds and Sundaland suggests subduction forces were the primary trigger for plate motions. Our reconstruction places a $\sim 280 \mathrm{~km}$ upper limit on the motion on the Red River Fault, and a $\sim 1400 \mathrm{~km}$ width to the paleo-South China Sea. This value is intermediate between the low estimates of Searle (2006) and the higher values of $>1000 \mathrm{~km}$ (Tapponnier et al. 1990).

References

Briais A, P Patriat and P Tapponnier. 1993. Updated interpretation of magnetic anomalies and seafloor spreading stages in the South China Sea: implications for the Tertiary tectonics of Southeast Asia. Journal of Geophysical Research 98: 6299-6328

Hutchison CS, SC Bergman, DA Swauger and JE Graves. 2000. A Miocene collisional belt in north Borneo: uplift mechanism and isostatic adjustment quantified by thermochronology. Journal of the Geological Society 157: 783-793

Morley CK. 2002. A tectonic model for the Tertiary evolution of strikeslip faults and rift basins in SE Asia. Tectonophysics 347(4): 189-215

Peltzer G and P Tapponnier. 1988. Formation and evolution of strike-slip faults, rifts, and basins during the India-Asia Collision: an experimental approach. Journal of Geophysical Research 93: 15085-15117

Searle MP. 2006. Role of the Red River Shear zone, Yunnan and Vietnam, in the continental extrusion of SE Asia. Journal of the Geological Society 163: 1025-1036

Tapponnier P. et al. 1990. The Ailao Shan/Red River metamorphic belt; Tertiary left-lateral shear between Indochina and South China. Nature 343(6257): 431-437

Tapponnier P, G Peltzer, GAY Le Dain, R Armijo and PR Cobbold. 1982. Propagating extrusion tectonics in Asia: New insights from simple experiments with plasticine. Geology 10: 611-616

Taylor B and DE Hayes. 1980. The tectonic evolution of the South China Basin. In: D Hayes (ed), The Tectonic and Geologic Evolution of Southeast Asian Seas and Islands. Geophysical Monograph. American Geophysical Union, Washington DC, p89-104 